\title{
Human serum albumin: twenty-three genetic variants and their population distribution
}

\author{
By L. R. WEITKAMP,* F. M. SALZANO $\dagger$ J. V. NEEL, $\ddagger$ F. PORTA, $\S$ \\ R. A. GEERDINK\| AND A. L. TÁRNOKY \\ * University of Rochester School of Medicine and Dentistry, Rochester, New York; \\ $\dagger$ Universidade Federal do Rio Grande do Sul, Pôrto Alegre, Brazil; \\ $\ddagger$ University of Michigan Medical School, Ann Arbor, Michigan; \\ $\S$ Ospedale Civile, Sondrio, Italy; \\ || Academic Hospital, Utrecht; $\uparrow$ Royal Berkshire Hospital, Reading
}

Human serum albumin has particular genetic interest because, like haemoglobin, it is abundant in blood, easily detected in a variety of electrophoretic systems, and subject to extensive incidental screening in clinical laboratories. Nevertheless, appreciation of the diversity and frequency of albumin variation has developed slowly. The first inherited, electrophoretically detectable variant of serum albumin was described by Knedel and, independently, by Nennstiel $\&$ Becht in 1957, but direct electrophoretic comparison of rare, inherited variants from a few unrelated families was reported only five years ago (Weitkamp et al. 1967). Predictably, several different types were found. Since then five different rapidly migrating variants (Lie-Injo et al. 1971), ten different slowly migrating variants (Weitkamp \& Buck, 1972) and probably three different dimeric variants (Weitkamp et al. 1972) have been distinguished by direct electrophoretic comparison. Many other variants have been reported (see below), some of which have been found different from some of the above by direct comparison (Arends et al. 1969; Tárnoky et al. 1970; Porta et al. 1972a,b). In this paper we distinguish at least 23 genetically determined varieties of albumin and summarize their distribution and frequency.

\section{MATERIALS AND METHODS}

The designation of each albumin variant and the source of the previously published variants used in this comparison are listed in Table 1. The variants were compared in three vertical starch-gel electrophoretic systems: acetate-EDTA at $\mathrm{pH} 5 \cdot 0$; tris-lithium-succinate-citrate at pH 6.0, and tris-EDTA-borate at $\mathrm{pH} 6 \cdot 9$, approximately as described by Weitkamp, Basu et al. (1969) except that the tris-EDTA-borate system was run for $21 \mathrm{hr}$.

\section{RESULTS}

In Fig. 1 are shown starch-gel electrophoretic comparisons in the three buffer systems of 13 new or newly described variants with 17 selected variants which on previous comparisons have been distinguishable into 15 different types (Lie-Injo et al. 1971; Weitkamp \& Buck, 1972). The distances separating the normal and variant albumin in each heterozygote for each buffer system are listed in Table 1.

Under these conditions $\mathrm{SO} / \mathrm{CZ}$ is not distinguishable from $\mathrm{B}$, Afghanistan is not distinguishable from Kashmir, Belém II is not distinguishable from Mexico, Belém III and Makiritare-2 
Table 1. Comparative mobility of human serum 'monomeric' albumin variants in three starch-gel electrophoretic systems: 20 distinguishable types

Electrophoretic separation $(\mathrm{mm})$ at gel buffer $\mathbf{p H} \dagger$

Identification *

I. Pollibauer

2. Belém I

3. B (family ro) $\mathrm{SO} / \mathrm{CZ}$

4. Roma

5. Gainesville (family 24)

6. Gombak, Paris (family II)

7. Afghanistan Kashmir

8. Santa Ana

9. $\mathrm{SO} / \mathrm{BS}$

Io. Cartago RSII

I1. Pushtoon RSI

12. Cayemite

13. Mexico (family 26) Belém II

14. Uinba

I5. Medán

16. Máku (family 33) Belém III Makiritare-2

17. Now Guinea (family 27) Reading (family 12)

18. Makiritare-3

19. Naskapi (family 15)

20. MI/Fast Gent (family 17 )
Source of variant

Geerdink, unpubl.

Franco, Ayres \& Salzano, unpubl.

Weitkamp et al. 1966

Porta et al. 1972

Ortali, unpubl.

Lau et al. 1969

Lie-Injo et al. 1971

Sandor et al. 1965

Weitkamp \& Buck, 1972

Tárnoky \& Dowding, r 969

Kueppers et al. 1969

Porta et al. $1972 b$

Lau et al. 1972

Ortali, unpubl.

Weitkamp \& Buck, 1972

Ortali, unpubl.

Weitkamp, Basu et al. 1969

Polesky et al. 1968

Franco, Ayres \& Salzano, unpubl. Weitkamp, Shreffler et al. I969

Lie-Injo et al. 197 I

Weitkamp \& Chagnon, 1968

Franco, Ayres \& Salzano, unpubl.

Tanis \& Neel, unpubl.

Weitkamp et al. I 968

Tárnoky \& Lestas, 1964

Tanis \& Neel, unpubl.

Weitkamp et al. I967

Petrini, cited in Porta et al. 1972a

Wieme, I960

\begin{tabular}{|c|c|c|}
\hline $5 \cdot 0$ & $6 \cdot 0$ & $6 \cdot 9$ \\
\hline I 5 & $7 \cdot 5$ & $4 \cdot 5$ \\
\hline I 3.5 & $8 \cdot 5$ & 5 \\
\hline 12 & $6 \cdot 5$ & $6 \cdot 5$ \\
\hline 12 & 7 & 7 \\
\hline 12 & 9 & 6 \\
\hline 12 & 7 & 4 \\
\hline ? 12 & $? 7$ & $?$ \\
\hline I I & $5 \cdot 5$ & 3 \\
\hline 9.5 & $6 \cdot 5$ & 6 \\
\hline 9.5 & 6 & $6 \cdot 5$ \\
\hline $6 \cdot 5$ & $3 \cdot 5$ & $5 \cdot 5$ \\
\hline $6 \cdot 5$ & Broad & $5 \cdot 5$ \\
\hline 6 & 5 & 4 \\
\hline 5 & $?$ & Broad \\
\hline 3 & 2 & 2 \\
\hline 3.5 & Broad & $?$ \\
\hline Broad & Broad & Broad \\
\hline Broad & 2 & 3.5 \\
\hline Broad & 2 & 4 \\
\hline Broad & 0 & 0 \\
\hline 3 & o & Broad \\
\hline 5.5 & Broad & 5 \\
\hline $5 \cdot 5$ & Broad & 5.5 \\
\hline 5.5 & Broad & 6 \\
\hline 6.5 & $5 \cdot 5$ & Broad \\
\hline $6 \cdot 5$ & 5.5 & Broad \\
\hline 7 & $4 \cdot 5$ & Broad \\
\hline $7 \cdot 5$ & 6 & 6 \\
\hline 9 & $8 \cdot 5$ & 6 \\
\hline $8 \cdot 5$ & $8 \cdot 5$ & $6 \cdot 5$ \\
\hline
\end{tabular}

* Family numbers specify the sera used as identified in Weitkamp, Franglen et al. (1969). Albumins RSI and RSII were too degraded to be certain of their relativo mobility.

$\dagger$ The first 14 are slowly migrating; 15-20 are rapidly migrating.

are not distinguishable from Máku, and MI/Fast is not distinguishable from Gent, although there do appear to be very slight differences in mobility. In fact, in all but perhaps the comparisons of Afghanistan and Kashmir, the very slight increase in separation of the variant and normal albumin in one sample compared to another corresponds to a relatively larger amount

\section{Legend to Fig. 1}

Fig. 1. Comparative mobility of human albumin variants. Vertical starch-gel electrophoresis of serum in three buffer systems. Origin is indicated by a dash; anode is at the top. Gels A : acetateEDTA, pH 5.0. Gels B: tris-lithium-succinate-citrate, pH 6.0. Gels C: tris-EDTA-borate, pH 6.9. 1, Pollibauer; 2, Belém I; 3, B (family 10); 4, SO/CZ; 5, Roma; 6, Gainesville (family 24); 7, Gombak ; 8, Paris (family 11) ; 9, Afghanistan; 10, Kashmir ; 11, Santa Ana ; 12, SO/BS ; 13, Cartago; 14, RS II ; 15, Pushtoon; 16, RS I; 17, Cayemite; 18, Mexico (family 26) ; 19, Belém II ; 20, Uinba; 21, normal serum; 22, Medán; 23, Máku (family 33); 24, Belém III; 25, Makiritare-2; 26, New Guinea (family 27); 27, Reading; 28, Makiritare-3; 29, Naskapi (family 15); 30, MI/Fast; 31 , Gent (family 17). References to the procedures and sources of the variants are given in the text and in Table 1. 

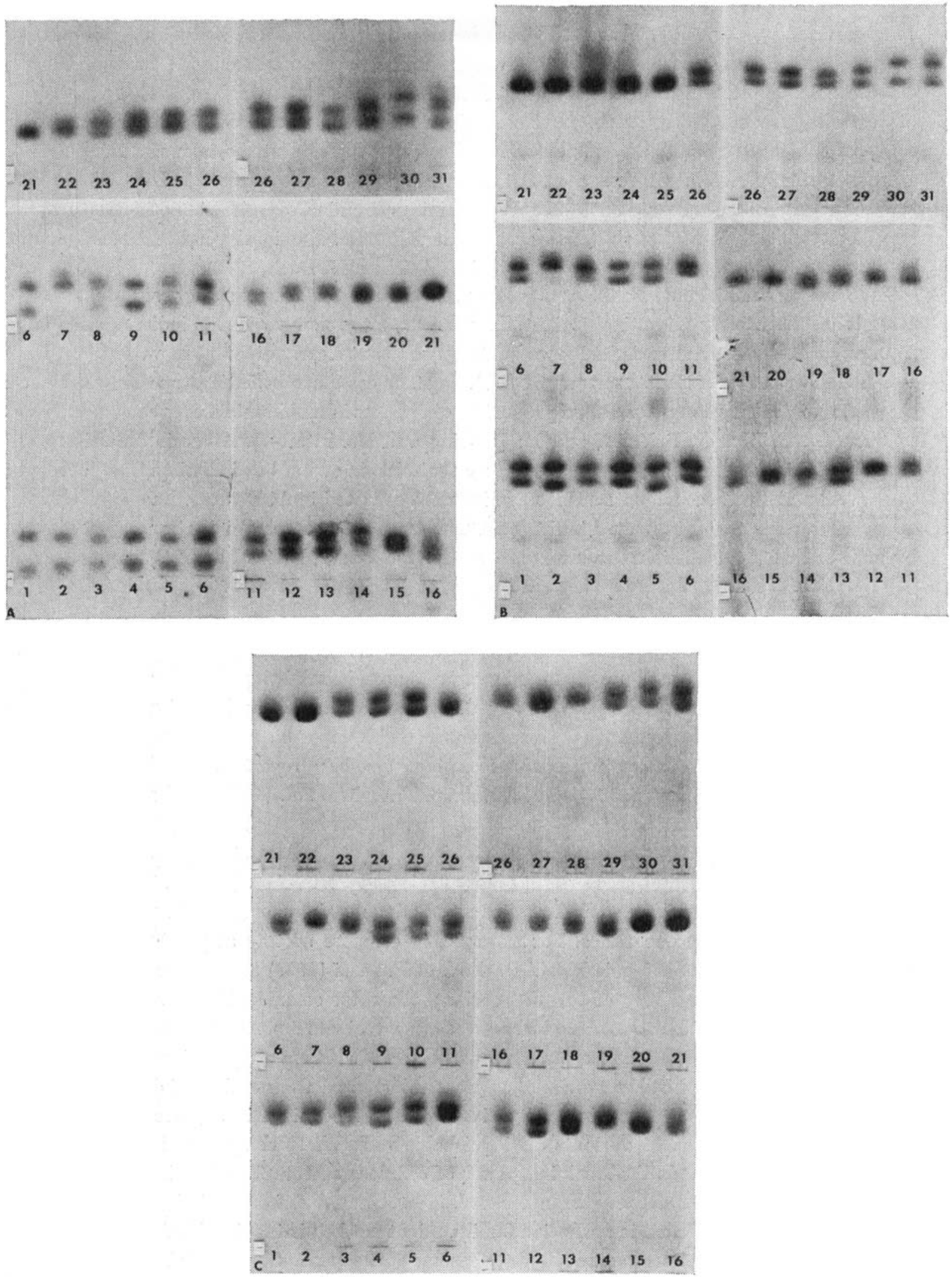

Fig. 1. For legend see facing page. 
of albumin in that sample application, as judged by the intensity of staining. At the time of comparison the sera with the variants RSI and RSII, both from East Africans of Indo-European origin (Somali Republic), were sufficiently degraded to preclude confidence in the determination of their mobility. Albumin Gombak, a variant found in two Malayan aborigines, has the property of degrading more rapidly than normal albumin in the same serum sample, this particular sample being no longer suitable. Previously, in two electrophoretic systems, it was indistinguishable from albumin Paris (Lie-Injo et al. 1971), a variant which also appears to have increased instability on prolonged storage. The sample containing albumin Cayemite did not demonstrate two distinct bands in any of the three systems at this time. Previously, it had been clearly distinguished from albumins Pushtoon and Mexico (Weitkamp \& Buck, 1972).

The new variants include Pollibauer, Belém I, Roma and SO/BS, all slowly migrating, and Makiritare-3, a rapidly migrating variant. In some cases the new variant is indistinguishable from previously described variants in two buffer systems but clearly different in a third (e.g. B, Roma, and Gainesville; Santa Ana and SO/BS). In other cases our belief that specific variants are distinguishable rests upon small, reproducible differences in mobility in more than one buffer system (c.g. Pollibauer, Belém I, and B; Reading and Makiritare-3). Albumin Makiritare-3 has the additional unusual property of being recognizable in serum but indistinguishable from normal albumin in those aliquots of blood which were collected in ACD tubes. Each of the five new variants was found in related individuals. The expected autosomal inheritance, indicated by male-to-male transmission, has been observed for Pollibauer, Belém I and SO/BS.

\section{DISCUSSION}

In this paper 20 different types of albumin variants have been distinguished by comparative starch-gel electrophoresis. These are clearly different from the dimeric variants, of which probably three different types have been recognized (Weitkamp et al. 1972). A number of other variants, not included in the current comparison, have also been reported. References to these are cited in Ungari \& Lopez (1965) and Weitkamp, Franglen et al. (1969), and more recently include, inter alia, Bonazzi (1968), Arends et al. (1969), Baisden et al. (1969), Tárnoky et al. (1970), Margni et al. (1970), Emanuelli et al. (1970), Fine (1970), Atal et al. (1970), Rose et al. (1971), McDermid (1971a,b), McDermid \& Vos (1971) and Porta et al. (1972b). Some of these variants have been previously compared with some of the variants examined here, but under different electrophoretic conditions. For example, in cellulose acetate at pH 8.6 Porta et al. $(1972 b)$ found SO/CZ indistinguishable from Z.N. of Bonazzi (1968) and 2836 of Fine (1970). Since $\mathrm{SO} / \mathrm{CZ}$ has the mobility of the ' $\mathrm{B}$ ' variant, the most common European variant (cf. Table 2), it is quite possible that these and several other variants reported by Bonazzi and Fine are further examples of albumin B occurring in the Italian and French populations. On the other hand, the use of several buffer systems has greatly increased the number of distinguishable types, for no more than 12-15 different variants can be recognized in any one of our three systems compared to the 20 variants distinguishable when all three systems are considered. Furthermore, in our hands the resolving power of cellulose acetate for albumin has been less than that of starch-gel (Weitkamp, Franglen et al. 1969). Thus, a variant as similar to albumin B as albumin Roma, also found in an Italian family, might not be distinguishable from albumin B in a single cellulose acetate system. Undoubtedly some of the previously reported variants repre- 
sent types distinguishable from the 20 types listed in Table 1, and, indeed, there is no assurance that additional electrophoretic systems would not permit the recognition of still additional types among the variants we have examined. We can conclude, however, that at least 23 different variant albumin types are now known.

Previously we have cited the distances separating normal and variant albumin bands in the three electrophoretic systems employed here (Lie-Injo et al. 1971; Lau et al. 1972; Weitkamp \& Buck, 1972). These relative mobilities, whether expressed in this manner or as an $R_{F}$ value, differ slightly from time to time, presumably because the conditions of electrophoresis have not been exactly reproduced. When the conditions are altered more markedly, as, for example, continuing electrophoresis in the tris-EDTA-borate, $\mathrm{pH} 6.9$ system for 19 or more hours instead of 5 or 6 , the differential effect on the mobility of two variants may be marked: during the shorter length of time the migration of albumin Naskapi is less than that of albumin Máku (Weitkamp \& Chagnon, 1968), whereas under the current longer-running-time Naskapi migrates farther than Máku. The difference probably reflects changing conditions in a discontinuous buffer system. Comparison of the present results with previously published results using approximately the same conditions, however, does indicate that each of the albumin variants, excepting the deteriorating samples of Gombak, Cayemite and possibly Paris, has continued to demonstrate the same relative mobility in each of the buffer systems even after, in some cases, prolonged storage and repeated thawing. The reproducibility of the differences under these circumstances adds credence to our opinion that normal albumin and most albumin variants are 'robust' molecules, that the small differences in electrophoretic mobility are not capricious.

Reversal in electrophoretic mobility of two albumin variants relative to each other in different buffer systems was first noted for albumins Máku and Naskapi (Weitkamp \& Chagnon, 1968). Máku migrated farther than Naskapi in the acetate-EDTA, $\mathrm{pH} 5 \cdot 0$ system and not as far as Naskapi in the short-run tris-EDTA-borate, $\mathrm{pH} 6.9$ system. The present comparison demonstrates 12 instances of reversal of relative mobility in different buffer systems (Pollibauer/ Belém I; Belém I/B; B/Roma; Paris/Kashmir; Paris/Santa Ana; Paris/Cartago; Paris/Mexico; Santa Ana/Cartago; Pushtoon/Mexico; Máku/Reading; Máku/Makiritare-3; Reading/Makiritare-3). In addition albumin Cayemite has a reversal in mobility relative to albumins Paris and Mexico under different electrophoretic conditions (Weitkamp, Basu et al. 1969).

Other instances of a reversal in the mobility of genetically determined variants of a protein under different electrophoretic conditions have been documented; for example, acid phosphatase (Harris et al. 1968) and glucose-6-phosphate dehydrogenase (cf. Giblett, 1969). It is becoming increasingly apparent that multiple buffer systems may be required to distinguish the maximum number of kinds among rare variants, as, for example, in the alkaline phosphatase (Robson \& Harris, 1967), phosphoglucoseisomerase (Welch, 1971) and glutamic-pyruvic transaminase (Chen et al. 1972) systems. However, the number of reports of an actual reversal in the relative mobility of two variants in different buffer systems is limited: our impression is that the frequency with which albumin variants reverse relative mobility under different conditions will prove exceptional among protein systems. This notion is consistent with the unusual conformational lability of albumin and its capacity for interaction with small ions (cf. Schultze \& Heremans, 1966). It raises the question of whether the proportion of different variants detectable and uniquely distinguishable by electrophoresis may be greater for albumin than for other proteins. 
Table 2. Population distribution of twenty-three variant albumin alleles*

\begin{tabular}{|c|c|c|c|}
\hline $\operatorname{Rac} \theta$ & Variant & $\begin{array}{l}\text { No. of } \\
\text { unrelated } \\
\text { families }\end{array}$ & Population \\
\hline Caucasoid & $\begin{array}{l}\text { Pollibauer } \\
\text { B (SO/CZ) } \\
\text { Roma } \\
\text { Gainesville } \\
\text { Paris (Gombak) } \\
\text { SO/BS } \\
\text { Cartago } \\
\text { Reading (New Guinea) } \\
\text { Gent (MI/Fast) } \\
\text { 'Dimer' }\end{array}$ & $\begin{array}{l}1 \\
2 \\
1 \\
1 \\
1 \\
3 \\
4 \\
7\end{array}$ & $\begin{array}{l}\text { Austrian descent (Holland) (I) } \\
\text { Swiss, Norwegian, Danish, Swedish, German, } \\
\text { English, Italian (I, 2, 3) } \\
\text { Italian (I) } \\
\text { English, Irish descent (U.S.A.) (3) } \\
\text { French (2) } \\
\text { Italian (4) } \\
\text { Spanish descent (Costa Rica) (5) } \\
\text { British, Greek, Swiss descent (U.S.A.) (2, 3,6) } \\
\text { Danish, Belgian, Italian (2, 7) } \\
\text { Welsh, Swedish (8) }\end{array}$ \\
\hline Negroid & $\begin{array}{l}\text { Cayemite } \\
\text { Uinba } \\
\text { New Guinea (Reading) } \\
\text { 'Dimer' }\end{array}$ & $\begin{array}{l}\mathbf{I} \\
\dagger \\
\vdots \\
\mathbf{I}\end{array}$ & $\begin{array}{l}\text { Negro (Haiti) (9) } \\
\text { New Guinea indigines (10) } \\
\text { New Guinea indigines (3) } \\
\text { Negro (U.S.A.) (8) }\end{array}$ \\
\hline Mongoloid & $\begin{array}{l}\text { Gombak (Paris) } \\
\text { Kashmir (Afghanistan) } \\
\text { Pushtoon } \\
\text { Mexico } \\
\text { Medán } \\
\text { Máku (Makiritare-2) } \\
\text { Makiritare-3 } \\
\text { Naskapi } \\
\text { Makiritare } \\
\text { Yanomama }\end{array}$ & $\begin{array}{l}\mathbf{I} \\
\vdots \\
\dagger \\
\S\end{array}$ & $\begin{array}{l}\text { Indonesian (I I) } \\
\text { Pushtoon (Afghanistan) (12, I3) } \\
\text { Pushtoon (Afghanistan) (13) } \\
\text { Indians of southwestern U.S.A. and Mexico } \\
(3,14,15) \\
\text { Malayan aborigine (1 I) } \\
\text { Yanomama (Venezuela), Makiritare (Brazil) } \\
\text { (I, 3) } \\
\text { Makiritare (Brazil) (I) } \\
\text { North American Indian (2, 3, 16, I 7) } \\
\text { Warao, Makiritare (Venezuela), Trio, Wajana } \\
\text { (Surinam) (I, 8) } \\
\text { Yanomama (Venezuela) (8) }\end{array}$ \\
\hline Unknown & $\begin{array}{l}\text { B } \\
\text { Santa Ana } \\
\text { Belém I } \\
\text { Belém II (Mexico) } \\
\text { Belém III (Málku) }\end{array}$ & $\left.\begin{array}{l}\mathbf{I} \\
\mathbf{1} \\
\S \\
\mathbf{I}\end{array}\right\}$ & $\begin{array}{l}\text { 'Negroid extraction' (U.S.A.) (3) } \\
\text { Caucasoid or Mongoloid (Mexico) (I } 8 \text { ) } \\
\text { Trihybrid group of Caucasoid, Negroid } \\
\text { and Mongoloid mixture (Brazil) }\end{array}$ \\
\hline
\end{tabular}

* Electrophoretic description of the 20 monomeric variants is given in Table I and Fig. I. Comparison of the three types of dimeric variants ('Dimer', albumins Yanomama and Makiritare) is described in Weitkamp et al. (1972).

$\dagger$ The population sample was such that the number of unrelated individuals could not be determined. The variant was found in a fow individuals in a single village.

\$ The number of unrelated individuals could not be determined, but the variant was found in more than one village and with a frequency sufficiently common $\left(\frac{1}{2}-2 \%\right)$ that further investigation may establish polymorphism in this or related populations.

$\S$ Clearly polymorphic in the populations indicated. Belém II was found in only one family.

(1) This paper. (2) Weitkamp et al. (1967). (3) Weitkamp, Franglen et al. (1969). (4) Porta et al. (1972b). (5) Lau et al. (1972). (6) Weitkamp et al. (1970). (7) Porta et al. (1972a). (8) Weitkamp et al. (1972). (9) Weitkamp, Basu et al. (1969). (10) Weitkamp, Shreffler et al. (1969). (1 I) Lie-Injo et al. (1971). (12) Tárnoky \& Dowding (1969). (1 3) Weitkamp \& Buck (1972). (14) Melartin et al. (1967). (1 5) Lisker et al. (1971). (16) Melartin (1967). (17) Melartin et al. (1968). (18) Kueppers et al. (1969). 
Table 3. Frequency of albumin variants in Europeans

\begin{tabular}{lll} 
Population & Frequency & \multicolumn{1}{c}{ Source } \\
English & o/12,000 & Cooke et al. 196I \\
Norwegian & $0 / 95^{\circ}$ & Efremov \& Braend, 1964 \\
Swedish & $6 / 475^{*}$ & Laurell \& Niléhn, 1966 \\
Finnish & $0 / 2682$ & Melartin, I967 \\
Italian & $5 / 12,000$ & Bonazzi, 1968 \\
French & $7 / 10,000 \dagger$ & Fine, 1970
\end{tabular}

* Dimer albumin. Five of the variants were found among 1550 orthopaedic patients.

$\dagger$ One additional variant (rapidly migrating) was reported, but its substantially decreased concentration, relative to normal albumin in the same sample, indicates it may be an instance of non-hereditary bisalbuminaemia.

The distribution of albumin variants among 'races' and population groups is given in Table 2 . The distribution does not reflect well the relative frequency of albumin variants in different populations. The European population, for example, has been extensively screened in the course of routine electrophoresis for clinical purposes. Unfortunately, new variants are usually reported without indication of the number of sera which were in effect incidentally screened. There are a few reports of prospective searches for albumin variants using techniques known to be capable of detecting at least some variants, in particular the widely distributed B variant. These are listed in Table 3 and suggest the frequency of albumin variants may be as low as 1 in 2000 in Europeans. The figure is slightly lower than the approximate 1 in 1000 frequency of 'private' variants for other proteins (summarized in Weitkamp, 1971), and is undoubtedly an underestimate for the following reason. In our first comparison of previously reported albumin variants (Weitkamp et al. 1967), 13 out of 15 European variants were of the slowly migrating $B$ or rapidly migrating Gent type. With the specimens collected since then, the incidence of these two types is now 18 out of 29 European monomeric variants. Both albumin B and Gent have a mobility greatly different from that of normal albumin; thus, these variants are more susceptible to detection under low-resolution conditions. The data in Table 3 are also compatible with the notion that the frequency with which albumin variants are detected has increased with newer electrophoretic techniques.

Amerindians have been subjected to specific screening for albumin variation in population surveys as a result of the early finding of polymorphism at this locus among the Naskapi (Melartin \& Blumberg, 1966). Six different variants have now been identified (Naskapi, Mexico, Makiritare, Máku, Yanomama, and Makiritare-3), with two others (Santa Ana, Belém I) possibly of Indian origin. Three of these are polymorphic in specific populations. The highest gene frequencies, up to $\mathbf{0 . 1 4}$, occur for the Naskapi variant which is limited to North American Indians and Eskimoes (Melartin, 1967; Weitkamp et al. 1967; Polesky \& Rokala, 1967; Melartin et al. 1968). Albumin Mexico has been found in the Indians of the south-western United States and Mexico at a gene frequency as high as 0.03 (Melartin et al. 1967; Melartin, 1967; Lisker et al. 1971). The variant here identified as Belém-II is the first case of a variant indistinguishable from albumin Mexico found outside this group (in a trihybrid Brazilian population). Previously, we have suggested that albumin Makiritare (Warao), a dimer, may be polymorphic among the Makiritare and Warao Indians (Arends et al. 1970). The finding of an indistinguishable dimer variant in 11 of 446 Trio and 12 of 259 Wajana of nearby Surinam (Geerdink, unpublished) brings the total to 41 instances of the variant among 1461 members of the four tribes, an average gene 
frequency of $0 \cdot 014$. In addition we note that the Máku type of variant, originally encountered in a captured Máku woman, two of her children, and a grandchild living among the Yanomama of southern Venezuela (Weitkamp \& Chagnon, 1968), has now been found in an individual from the Makiritare tribe in adjacent north-central Brazil (Makiritare-2) and in another individual in a trihybrid population in northern Brazil (Belém III).

The picture which emerges is a relatively high degree of polymorphism for the Naskapi variant in northern North America, a lower-frequency polymorphism for the Mexico variant, in southern North America, and a low-frequency polymorphism for the Makiritare variant in northern South America, as well as at least three uncommon South American variants, one of which has been found in three different groups. The fact that repeated instances of the Naskapi, Mexico, Makiritare and Máku variants have been found in Amerindians and that, despite the large number of albumin variants now known, electrophoretically similar variants have not been found in other populations argues for the notion that the four variants may represent only four different alleles. The decline in frequency and the stratification with respect to type is apparent, and possibly relates in some manner to the north-to-south migration of the American Indian. The finding of four different albumin variants in the Yanomama and Makiritare Indians of Venezuela and Brazil also has special interest because it occurs in the context of the finding that these Indians are extraordinarily invariant with respect to other proteins (Weitkamp \& Neel, 1972).

Two additional populations deserve comment. Albumin New Guinea was initially found in several widely separated New Guinea villages, indicating a possible low-frequency polymorphism in this group (Weitkamp, Shreffler et al. 1969). A subsequent study of albumin variation in New Guinea indigenes has resulted in the finding of another individual with a variant of probably similar mobility (MeDermid, 1971b). Albumin Kashmir was found in a London Moslem family originally from Kashmir (Tárnoky \& Dowding, 1969). Recently two different variants, each with 1-2\% gene frequency, were found in a Pushtoon village which had migrated from a region in Afghanistan adjacent to Kashmir (Weitkamp \& Buck, 1972). One of the variants, albumin Afghanistan, has now been found indistinguishable from albumin Kashmir. The data are limited, but do raise the possibility of low-frequency albumin polymorphisms in the cited populations.

We have argued that the proportion of variants uniquely distinguished by electrophoresis may be greater for albumin than for other proteins. One measure of the validity of this proposition is to determine the molecular basis of rare, electrophoretically indistinguishable variants from unrelated families and compare the results to those obtained for other proteins. The first two variants for which an amino acid substitution has been determined, both examples of albumin B (family 9, German descent, and family 10, Danish descent, in Weitkamp et al. 1967), have identical amino acid substitutions (Winter et al. 1972) and very probably the same substitution as a third example of albumin B (family 3 , Norwegian descent) studied by Gitlin et al. (1961). Clearly, this is only a beginning. However, the determination of the proportion of albumin variants uniquely distinguishable by electrophoresis is important in comparing the frequency of albumin variation to that of other proteins. Furthermore, as an indication of the extent to which variant alleles for this protein may be detectable by electrophoresis, it is important with regard to the use of the albumin system - for example, in monitoring the human germinal mutation rate (cf. Neel, 1971; Weitkamp, 1971). 
The question which we initially posed in the comparison of electrophoretic variants of human albumin (Weitkamp et al. 1967) was whether the previously published reports of rare variants represented recurrent discoveries of a few electrophoretically distinguishable types or many different types. The question of real interest, however, is the frequency of each of the albumin alleles. To the evidence suggesting that three of the B-type electrophoretic variants are produced by alleles giving the same amino acid substitution may be added the observation that the peptide maps of two other families with slowly migrating variants, one of Italian and one of German origin, may resemble the albumin B pattern (Margni et al. 1970). Supposing that all of the $B$ variants are indeed products of a single $B$ allele, a curious situation exists. The $B$ allele is widely, though sparsely, distributed through Europeans of different ethnic origin and therefore seems unlikely to result from a founder effect. It is clearly not polymorphic, having a frequency of no more than 1 in 1000 and perhaps as little as 1 in 10,000. Yet the $B$ variant probably has a frequency in Europeans higher than that in other populations and, although more readily detectable than many other variants, may have an unusually high frequency compared to other rare variants in Europeans. There is a hint that random mutation and drift may be insufficient to explain its frequency in relation to other rare variants in this population.

As with most proteins, the functional significance of genetic variation in albumin is unknown. Since albumin is the major protein involved in the blood transport of various biologically active compounds, it seems possible that functional consequence might be attached to some of the variants. However, individuals with analbuminaemia, though rare, apparently suffer from little more than oedema (Bennhold et al. 1954; Gordon et al. 1959). Nevertheless, untoward effects could result from unusual binding properties of the variant albumin toward exogenous substances such as drugs.

An unusual type of variant is the 'dimer'. Increased dimerization of albumin may occur apparently as a result of structural alteration due to allelic variation at the albumin locus (Weitkamp et al. 1968, 1972; Jamieson \& Ganguly, 1969). Whether dimerization has an adverse clinical effect has not been established, but Laurell \& Nilehn (1966) do suggest that for the dimer variant found in Sweden there may be an association with disease of supporting tissues.

\section{SUMMARY}

Twenty different 'monomeric' variants of albumin have been distinguished using three starch-gel electrophoretic systems. The value of a multiple system comparison is demonstrated by the fact that no more than 12-15 variants were distinguishable in any one of the three systems. There were 12 instances in which a given variant migrated farther than another variant in one buffer system, but not as far as this same variant in a second buffer system. The finding is probably explained by the unusual capacity of albumin to interact with small ions and is an indication that the proportion of variants distinguishable by electrophoresis may be greater for albumin than for other proteins.

The population distribution of the 20 different monomeric variants plus three dimeric variants is listed. There are three clearly polymorphic variants, all of which occur in Amerindians. Three other variants may achieve polymorphic frequency, one in New Guinea 
and two in Afghanistan. Albumin B, the most common European variant and possibly the product of a single allele, has a frequency of less than 1 in 1000 and yet is widely distributed among Europeans of different ethnic origin.

We are indebted in particular to Drs Ayres, Franco, Ortali, Petrini and Tanis and also to our many colleagues acknowledged in Table 1 for making available some of the serum samples and to Ms Johnston and Guttormsen for technical assistance. This work was supported in part by U.S. National Institutes of Health Research Career Development Award 5 K04HD 50248 (L. R.W.), by the Câmara Especial de Pós-graduação e Pesquisa da Universidade Federal do Rio Grande do Sul, Conselho Nacional de Pesquisas, Coordenação do Aperfeiçoamento do Pessoal de Nível Superior, and Fundação de Amparo à Pesquisa do Estado do Rio Grande do Sul, and by U.S. Atomic Energy Commission Contract AT (11-1) 1552.

\section{REFERENCES}

Arends, T., Gallango, M. L., Layrisse, M., Wilbert, J., Heinen, H. D. (1969). Albumin Warao: New typo of human alloalbuminemia. Blood 33, 414.

arends, T., Weitkamp, L. R., Gallango, M. L., Neel, J. V. \& Schultz, J. (1970). Gene frequencies and microdifferentiation among the Makiritare Indians. II. Seven serum protein systems. Am. J. Hum. Genet. 22, 526 .

Atal, P. R., Mital, V. P. \& Kulshrestha, R. C. (1970). Heterogeneity of human serum albumin. Report of a case of bisalbuminemia. Ind. J. Med. Sci. 12, 797.

Baisden, R., Conn, R. B. \& Anido, V. (1969). Heterogeneity of human serum albumin. Report of two cases of bisalbuminemia. Am. J. Clin. Path. 51, 760.

Bennhold, H., Peters, H. \& Roth, E. (1954). Über einen Fall von kompletter Analbuminämie ohne wesentliche Klinische Krankheitszeichen. Deutsch Gesel. Inneremed. 60, 630.

Bonazzi, L. (1968). On a rare genetic variation of plasma albumin: bisalbuminemia. Clin. Chim. Acta 20, 362.

Chen, S.-H., Giblett, E. R., Anderson, J. E. \& Fonsum, B. L. G. (1972). Geneties of glutamic-pyruvic transaminase: its inheritance, common and rare variants, population distribution and differences in catalytic activity. Ann. Hum. Genet. (Lond.) 35, 401.

Cooke, K. B., Cleghorn, T. E. \& Lockey, E. (1961). Two new families with bisalbuminemia: An examination of possible links with other genetically controlled variants. Biochem. J. 81, $39 P$.

Efremov, G. \& Braend, M. (1964). Serum albumin: Polymorphism in man. Science, N.Y. 146, 1679).

Emanuelli, G., Monni, A., Congiu, P., Palomba, V. \& Pilleri, G. (1970). Bisalbuminemia of the fast type. Acta haemat. 44, 246.

Fine, J. M. (1970). Les allotypes de l'albumine humaine. Étude de 8 cas de bisalbuminémie observés en France. Rev. Europ. Etudes Clin. Biol. 15, 113.

Giblett, E. R. (1969). Genetic Markers in Human Blood, p. 456. Philadelphia: F. A. Davis.

Gitlin, D., Schmid, K., Earle, D. P. \& Givelber, H. (1961). Observations on double albumin. II. A peptide difference between two genetically determined human serum albumins. J. Clin. Invest. 40, 820.

Gordon, R. S., JR., BartTer, F. C. \& Waldmann, T. (1959). Idiopathic hypoalbuminemias. (Clinical Staff Conferences at the National Institutes of Health.) Ann. Int. Med. 51, 553.

Harris, H., Hopkinson, D. A., Luffman, J. E. \& Rapley, S. (1968). Electrophoretic variation in erythro. cyte enzymes. In Hereditary Disorders of Erythrocyte Metabolism, vol. I (ed. E. Beutler), pp. 1-20. City of Hope Symposium Series. New York: Grune and Stratton.

Jamieson, G. A. \& Ganguly, P. (1969). Studies on a genetically determined albumin dimer. Biochem. Genet. 3, 403.

Knedel, M. (1957). Die Doppel-Albuminämie, eine neue erbliche Proteinanomalie. Blut 3, 129.

Kueppens, F., Holland, P. V. \& Weitkamp, L. R. (1969). Albumin Santa Ana. A new inherited variant. Human Hered. 19, 378.

Lau, T., Sunderman, F. W. Jr., Agarwal, S. S., Sutnick, A. I. \& Blumberg, B. S. (1969). Genetics of albumin Gainesville. A new variant of human serum albumin. Nature, Lond. 221, 66.

Lau, 'T. J., Sunderman, F. W. Jr., Weitkamp, L. R., Agarwal, S. S., Sutwick, A. I., Blumberg, B. S. \& Carrillo de Jimenez, R. B. (1972). Albumin Cartago: a 'new' slow moving alloalbumin. Am. J. Clin. Path. 57, 247.

Laureli, C.-B. \& Niléhn, J.-E. (1966). A new type of inherited serum albumin anomaly. J. Clin. Invest. 45, 1935.

Lisker, R., Сово, L. \& MorA, G. (1971). Distribution of albumin variants in Indians and non-Indians of Mexico. Am. J. Phys. Anthrop. 35, 119. 
Lie-Injo, L. E., Weitkamp, L. R., Kosasih, E. N., Bolton, J. M. \& Moore, C. L. (1971). Unusual albumin variants in Indonesians and Malayan aborigines. Hum. Hered. 21, 376.

Marani, R. A., Heer, E. E., Acerbo, E., Hajos, S., Beliveau, M. \& Bobbi, M. E. (1970). Immunochemical and genetic studies in two bisalbuminemic families. Clin. Chim. Acta 29, 219.

MoDermid, E. M. (1971a). Serum albumin variation in Indian populations. Vox Sang. $21,462$.

McDermid, E. M. $(1971 b)$. Variants in human serum albumin and caeruloplasmin in populations from Australia, New Guinea, South Africa and India. Aust. J. Exp. Biol. Med. Sci. 49, 309.

MoDermid, E. M. \& Vos, G. H. (1971). Serum protein groups of South African Indians. S. Afr. J. Med. Sci. 36, 57.

Melartin, L. (1967). Albumin polymorphism in man. Acta Path. Microb. Scand. Supplementum $191,1$.

Melartin, L. \& Blumbera, B. S. (1966). Albumin Naskapi : a new variant of serum albumin. Science, N.Y. $153,1664$.

Melartin, L., Blumbera, B. S. \& Lisker, R. (1967). Albumin Mexico. A new variant of serum albumin. Nature, Lond. 215, 1288.

Melartin, L., Blumbera, B. S. \& Martin, J. R. (1968). Albumin polymorphism (Albumin Naskapi) in Eskimoes and Navajos. Nature, Lond. 218, 787.

NeEL, J.V.(1971). The detection of increased mutation rates in human populations. Perspect. Biol.Med.14, 522.

Nennstiel, H. J. \& BeChт, T. (1957). Über das erbliche Auftreten einer Albuminspaltung im Elektrophoresediagramm. Klin. Wsehr. 35, 689.

Polesky, H. F. \& Rokala, D. A. (1967). Serum albumin polymorphism in North American Indians. Nature, Lond. 216, 184.

Polesky, H. F., Rokala, D. A. \& Burch, T. (1968). Serum albumin polymorphism in Indians of the Southwestern United States. Cited in Weitkamp, Franglen et al. (1969).

Porta, F., Ruffini, G., Ortal, V. \& Fisauli, F. (1972a). Alloalbuminemia. Analytical separation by electrophoretic procedure. Proc. Int. Symp. on Standardization in Haematology and Clinical Pathology, Sept. 1971, pp. 241-6. Foggia (Italy): S. Giovanni Rotondo.

Porta, F., Ruffini, G., Pasino, M. \& Scherini, A. (1972b). Alloalbuminemia (bisalbuminemia) di tipo lento. Minerva Med., Roma 63, 1316.

Robson, E. B. \& Harris, H. (1967). Further studies on the genetics of placental alkaline phosphatase. Ann. Hum. Genet. (Lond.) 30, 219.

Rose, M., Blaszozyk, J. \& Geserick, G. (1971). Eine humane Serumalbuminvariante (Doppelalbuminamie). Humangenetik 11, 132.

Sandor, G., Martin, I., Porsin, M., Rousseau, A. \& Martin, R. (1965). A new bisalbuminaemic family. Nature, Lond. 308, 1222.

Schultze, H. E. \& Heremans, J. F. (1966). Molecular Biology of Human Proteins, vol. 1, p. 403. Amsterdam: Elsevier.

Tárnoky, A. L. \& Dowding, B. (1969). Albumin Kashmir. A new variant and its behavior on routine analysis. Clin. Chim. Acta 26, 455.

Tárnoky, A. L. \& Lestas, A. N. (1964). A new type of bisalbuminemia. Clin. Chim. Acta 9, 551.

Tárnoky, A. L., Dowding, B. \& Lakin, A. L. (1970). Eight types of bisalbuminemia. Nature, Lond. $225,742$.

Ungari, S. \& Lopez, V. (1965). Doppia albuminemia. Min. Pediat. 17, 288.

Weitkamp, L. (1971). Prospects for the automated typing of biochemical markers for the purpose of monitoring the human germinal mutation rate. In Monitoring, Birth Defects and Environment (ed. E. B. Hook, D. T. Janerich and I. H. Porter), p. 217. New York: Academic Press.

Weitkamp, L. R., Arends, T., Gallango, M. L., Neel, J. V., Schultz, J. \& Shreffler, D. C. (1972). The genetic structure of a tribal population, the Yanomama Indians. III. Seven serum protein systems. Ann. Hum. Genet. (Lond.) 35, 271.

Weitkamp, L. R., Basu, A., Gald, J. C. \& Brown, W. (1969). Albumin Cayemite: a Negro plasma albumin variant. Humangenetik 7, 180.

Weitkamp, L. R. \& Buck, A. A. (1972). Phenotype frequencies for four serum proteins in Afghanistan: two 'new' albumin variants. Humangenetik 15, 335 .

Weitkamp, L. R. \& Chagnon, N. A. (1968). Albumin Máku. A new variant of human serum albumin. Nature, Lond. 217, 759.

Weitkamp, L., Chagnon, N., Saave, J., Salzano, F. \& Gall, J. (1968). Serum albumin variants in American and Now Guinea indigenes. Clin. Res. 16, 298.

Weitkamp, L. R., Franglen, G., Rokala, D. A., Polesky, H. F., Simpson, N. E., Sunderman, F. W. Jr., Bell, H. E., SAave, J., Lisker, R. \& Bohls, S. W. (1969). An electrophoretic comparison of human serum albumin variants. Eight distinguishable types. Hum. Hered. 19, 159.

Weitkamp, L. R. \& Neel, J. V. (1972). The genotic structure of a tribal population, the Yanomama Indians. IV. Eleven erythrocyte enzymes and summary of protein variants. Ann. Hum. Genet. (Lond.) 35, 433. 
Weitkani, L. R., Renwick, J. H., Berger, J., Shreffler, D. C., Drachmann, O., Wuhrmann, F., Braend, M. \& Franglen, G. (1970). Additional data and summary for albumin-Ge linkage in man. Hum. Hered. 20, 1.

Weithamp, L. R., Robson, E. B., Shrefrler, D. C. Corney, G. (1968). An unusual human serum albumin variant: Further data on genetic linkage between loci for human serum albumin and group-specific component (G) . Am. J. Hum. Genet. 20, 392.

Weitkamp, L. R., Rucknagel, D. L. \& Gershowitz, H. (1966). Genetic linkage between structural loei for albumin and group specific component (Ge). Am. J. Hum. Genet. 18, 559.

Weitkamp, L. R., Shreffler, D. C., Robins, J. L., Drachmann, O., Adner, P. L., Wigme, R. J., Simon, N. M., Cooke, K. B., Sandor, G., Whurmane, F., Braend, M. \& Tárnoky, A. L. (1967). An electrophoretic comparison of serum albumin variants from nineteen unrelated families. Acta Genet. Stat. Med. 17, 399.

Weitkamp, L. R., Shreffler, D. C. \& SaAve, J. (1969). Serum albumin variants in New Guinea indigene's. Fo.x Sang. 17, 237.

WELCH, S. G. (1971). Qualitative and quantitative variants of human phosphoglucose isomerase. Hum. Hered. 21, 467.

WIEME, R. J. (1960). On the presence of two albumins in certain normal human sera and its genetie determination. Clin. Chim. Acta 5, 443.

Winter, W. P., Weitkamp, L. R. \& Rucknagel, D. L. (1972). Amino acid substitution in two identical inherited human serum albumin variants: albumin Oliphant and albumin Ann Arbor. Biochemistry 11, 889. 